\title{
ACCESSIBLE GENETICS RESEARCH ETHICS EDUCATION (AGREE): A WEB-BASED PROGRAM FOR IRBS AND INVESTIGATORS
}

Grant No. DE-FG02-02ER63433

FINAL REPORT (7/13/04)

With funding from the Department of Energy, AGREE now provides a web-based educational program for members of institutional review boards and investigators concerning the ethical issues associated with genetics. Funding through the end of the project period (12/31/03) made possible the development of the publicly available web site [http://agree.mc.duke.edu]. The site currently features two modules ("Ethics and Genetics Research in Populations", "Ethics in Behavioral Genetics Research"). Each module is available for free and can be viewed in one of three ways: audio streaming, HTML, and as a PDF file. A knowledge quiz and evaluation can be completed on-line following each module. For a fee of $\$ 25, \mathrm{CME}$ credits are available for interested users. The AGREE site also provides audio streaming of three talks regarding ethics and genetics from a national conference, Working at the Frontiers of Law and Science: Applications of the Human Genome held October 2-3, 2003 at the University of North Carolina at Chapel Hill. Finally, the AGREE site has a listing of General Resources in ethics and genetics as well as information about the AGREE team and the Expert Advisory Panel.

The decisions regarding the topics to include in the modules were based on a needs assessment with experts and non-experts. The development of each module involves a series of steps: (1) background research by the AGREE team; (2) production of a draft presentation that is circulated to the expert advisory committee and some users; (3) initial production of a web-based version that includes graphics; (4) review by the AGREE team; (5) revision of the web-based version; (6) final expert review, pilot testing by users, and CME review; (7) final revisions; and (8) posting. In addition, the background papers for the first two educational modules have been published (attached) in the peer-reviewed literature:

DeCamp M, Sugarman J. Ethics in population-based genetic research. Accountability in Research 2004; 11: 1-26. - COPYRIGHTED

DeCamp M, Sugarman J. Ethics in behavioral genetics research. Accountability in Research 2004; 11:27-47. - COPYRIGHTED

Work on AGREE will continue under a separate grant to the Johns Hopkins University. Plans for this project include the development of three additional modules, program evaluation, and dissemination.

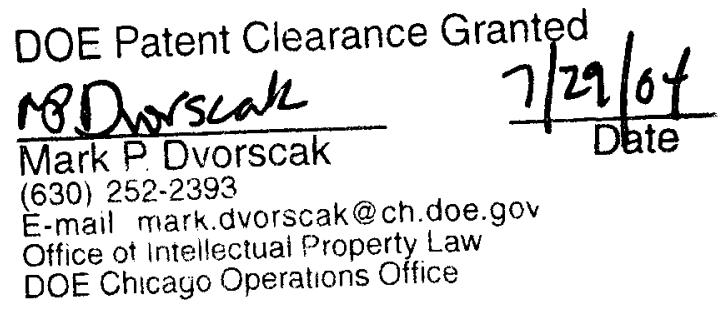




\section{DISCLAIMER}

This report was prepared as an account of work sponsored by an agency of the United States Government. Neither the United States Government nor any agency thereof, nor any of their employees, makes any wartanty, express or implied, or assumes any legal liability or responsibility for the accuracy, completeness, or usefulness of any information, apparatus, product, or process disclosed, or represents that its use would not infringe privately owned rights. Reference herein to any specific commercial product, process, or service by trade name, trademark, manufacturer, or otherwise does not necessarily constitute or imply its endorsement, recommendation, or favoring by the United States Government or any agency thereof. The views and opinions of authors expressed herein do not necessarily state or reflect those of the United States Government or any agency thereof. 


\section{DISCLAIMER}

Portions of this document may be illegible in electronic image products. Images are produced from the best available original document. 